\title{
Multi-Target Inhibition of Cancer Cell Growth by SiRNA Cocktails and 5-Fluorouracil Using Effective Piperidine-Terminated Phosphorus Dendrimers
}

\author{
Aliaksei Ihnatsyeu-Kachan ${ }^{1}$, Volha Dzmitruk ${ }^{1}$, Evgeny Apartsin ${ }^{2}$ (D), Olga Krasheninina ${ }^{2}$ (D), \\ Maksim Ionov ${ }^{3}$, Svetlana Loznikova ${ }^{1}$, Alya Venyaminova ${ }^{2}$, Katarzyna Miłowska ${ }^{3}$, \\ Dzmitry Shcharbin 1,* (D), Serge Mignani 4,5, Maria Angeles Muñoz-Fernández 6,7, \\ Jean-Pierre Majoral ${ }^{8,9}$ and Maria Bryszewska ${ }^{3}$ \\ 1 Institute of Biophysics and Cell Engineering of NASB, 220072 Minsk, Belarus; \\ alexei.ihn.k@gmail.com (A.I.-K.); dmitruk.olga@gmail.com (V.D.); s_loznikova@mail.ru (S.L.) \\ 2 Institute of Chemical Biology and Fundamental Medicine SB RAS, Novosibirsk 630090, Russia; \\ eka@niboch.nsc.ru (E.A.); Okrasheninina@gmail.com (O.K.); ven@niboch.nsc.ru (A.V.) \\ 3 Department of General Biophysics, Faculty of Biology and Environmental Protection, University of Lodz, \\ 90-236 Lodz, Poland; maksion@biol.uni.lodz.pl (M.I.); milowska@biol.uni.lodz.pl (K.M.); \\ marbrys@biol.uni.lodz.pl (M.B.) \\ 4 Laboratoire de Chimie et de Biochimie Pharmacologiques et Toxicologiques, Université Paris Descartes, \\ PRES Sorbonne Paris Cité, CNRS UMR 8601, 75006 Paris, France; serge.mignani@parisdescartes.fr \\ 5 Centro de Química da Madeira, MMRG, Universidade da Madeira, 9000-390 Funchal, Portugal \\ 6 Networking Research Centre on Bioengineering, Biomaterials and Nanomedicine, CIBER-BBN, \\ 28029 Madrid, Spain; mmunoz.hgugm@gmail.com \\ 7 Laboratorio de Inmunobiología Molecular, Hospital General Universitario Gregorio Marañón, \\ 28007 Madrid, Spain \\ 8 Laboratoire de Chimie de Coordination du CNRS, 31077 Toulouse CEDEX 4, France; majoral@lcc-toulouse.fr \\ 9 Université de Toulouse, UPS, INP, 31077 Toulouse CEDEX 4, France \\ * Correspondence: shcharbin@gmail.com; Tel.: +375-17-284-23-58; Fax: +375-17-284-23-59
}

Received: 9 October 2017; Accepted: 10 November 2017; Published: 13 November 2017

\begin{abstract}
Currently, RNAi based approaches for cancer treatment involving short double stranded RNA molecules (siRNA) are under vigorous scrutinization. Due to numerous biological obstacles, siRNA delivery into target cells requires protective escort. On the other hand, combining of siRNA-mediated gene silencing and action of conventional chemotherapeutics can propose additional enhancement of anticancer activity. In the present study, we investigated a siRNA cocktail able to downregulate anti-apoptotic genes $(B C L-x L, B C L-2, M C L-1)$ and the chemotherapeutic agent 5-fluorouracil (5-FU) to evaluate multi-target cytotoxic effect on human cervical carcinoma cells (HeLa cell line). Novel phosphorus containing dendrimers of 3rd and 4th generations (namely AE2G3 and AE2G4) with voluminous piperidine terminal cationic groups were designed and tested as siRNA carriers. Dendrimers of both generations showed remarkable ability to bind pro-apoptotic siRNAs and provided $80-100 \%$ siRNA uptake by HeLa cells in the serum containing medium, while the widespread transfection agent Lipofectamine showed only $\sim 40 \%$ uptake. SiRNA cocktail (in low concentrations 50 and $100 \mathrm{nM}$ ) delivered by AE2G3 dendrimer caused almost complete elimination of cancer cells. We have discovered considerable increase of 5-FU cytotoxic effect by addition of AE2G3/siRNA cocktail complexes in low doses. Thus, we demonstrated the effectiveness of combined multi-target siRNA anticancer approach and described new highly effective serum stable nanomaterial vehicle for gene-based drugs.
\end{abstract}

Keywords: phosphorus dendrimers; siRNA; 5-fluorouracil; cancer; combination therapy 


\section{Introduction}

The discovery of the double-stranded RNA-mediated interference (RNAi), which is a simple and rapid post-transcriptional method of inhibition of gene expression in organisms, represents an important tool in medicine. The silencing is based on short double-stranded RNA molecules (short interfering RNA, siRNA) that activate ribonucleases to target homologous mRNA. RNAi is very important process in both functional genomics and gene-specific therapeutic applications [1].

The possibility to knock-down a gene-specific therapeutic activity in the treatment of cancers has been intensively documented [2]. However, using siRNAs as anticancer agents requires intravenous administration associated with several intrinsic problems, such as their degradation by plasma nucleases, poor ability to penetrate into cells and rapid systemic removal by glomerular filtration. Moreover, intracellular breakdown by lysosomal enzymes diminishes the activity of siRNA therapeutics [2,3]. Thus, overcoming the barriers to siRNA delivery remains one of the main issues in the development of RNAi strategy to combat cancers [2].

Dendrimers, a class of nanoscale hyperbranched polymers with radial symmetry, represent one of the most promising tools for delivering of therapeutic genetic material into cancer cells [4-7]. Their well-defined structure with multivalent surface groups being, for instance, positively charged allows siRNAs to bind to them, thereby forming stable complexes called dendriplexes. Importantly, dendrimers can protect siRNAs against enzymatic degradation, contributing towards cellular uptake and release of siRNAs inside cells [5,6].

The ongoing advancement in dendrimer structures is aimed to design a transporting molecule, which can deliver drugs efficiently. New dendrimeric delivery systems for siRNAs should meet such requirements as appropriate drug binding properties, transfection efficiency and low cytotoxicity. Among many types of dendrimers, cationic phosphorus-containing dendrimers (CPD) lend themselves as promising delivery platforms for delivery of siRNAs.

CPD have been previously investigated in numerous biomedical applications [8-12]. With regard to transfection studies, most widely investigated group of CPD is diethylamine-terminated dendrimers with cyclotriphosphazene core. They were successfully implemented as carriers of plasmids [13-15], oligodeoxynucleotides [14,16] and siRNAs [17]. Loup et al. [13] highlighted better transfection efficiency of dendrimers of this group in the presence of serum than its absence during their plasmid transfection study. For the first time, Padié et al. [18] decorated the surface of cyclotriphosphazene core dendrimers with such a cyclic amine as pyrrolidine. Pyrrolidine-terminated dendrimers were found low-toxic, efficient to form dendriplexes and, among other modifications, exhibited remarkable transfection efficiency.

Two major studies concerning binding properties of CPD towards siRNAs involved diethylamine-terminated dendrimers and were focused on siRNA directed against $B C R$ [19] and anti-apoptotic genes (MCL-1, BCL- $x L$ and BCL-2) [20]. Both studies report stable complex formation between $\mathrm{CPD}$ and siRNAs, with complexes being positively charged and secondary structure of siRNA unaltered. Overall, various biophysical techniques indicated different ratios of sustainable complex formation with a steady excess of dendrimers' positive charge over negative charge of siRNAs. All methods collectively demonstrated stable dendriplex formation at not less than 5-fold excess of positive charges.

However, diethylamine-terminated CPD raised a concern regarding their cytotoxicity. As Lazniewska et al. [21] reported, the treatment of murine neural cells by these dendrimers at concentrations above $1 \mu \mathrm{M}$ was followed by a dramatic decrease in cell viability. After investigation of cell death-related processes, authors concluded that CPD treatment leads to necrotic cell death and proposed to improve biomedical potential of dendrimers by the modification of CPD surface with chemical groups lowering their cytotoxicity.

One of the proposed strategies to treat cancerous conditions is to alter the expression of anti-apoptotic genes [22]. Such genes of the Bcl-2 family as $M C L-1, B C L-x L$ and $B C L-2$ regulate cell death and are responsible for suppression of apoptosis. Being overexpressed in many types of cancer, 
these genes allow malignant cells to survive and grow by impairing essential signaling processes that lead to programmed cell death [23]. RNAi-based downregulation of the aforementioned genes triggers cell death in ovarian cancers [24], breast cancers [25,26], pancreatic cancers [27], acute myeloid leukemia [28] and skin cancers [29]. Silencing of BCL-2 family genes is also known to increase the sensitization of various cancer cells types to drugs commonly used in chemotherapy such as cisplatin [24], doxorubicin [26], etoposide [28] and 5-fluorouracil [30].

In the current study, we focused on the design of new phosphorus dendrimers. As dendrimers decorated with cyclic amines were efficient for cell transfection, successfully formed dendriplexes and were considered to be low-toxic [18], we decided to amend diethylamine-terminated CPD with piperidine surface modification. Novel structure was expected to possess shielded cationic termini with more distributed charge density compared to diethylamine-terminated CPD. We assumed that piperidine-terminated dendrimers would have weaker interactions with siRNAs (resulting in facilitation of intracellular siRNA release), as well as reduced impact on the cell membrane (resulting in reduced cytotoxic effects).

An effective application of the cocktail of pro-apoptotic siRNAs (siBCL-2, siBCL-xL, siMCL-1) for inhibition of cancer cells viability was reported in previous studies $[17,20]$. Here, we report on novel cationic phosphorus containing dendrimers of 3rd and 4th generations grafted with piperidine groups on the periphery that were synthesized and tested as siRNA carriers for RNAi-based cancer gene therapy with a chemotherapeutic combination approach. The objectives of this original study can be listed as follows: (1) to synthesize new piperidine-terminated cationic phosphorus dendrimers; (2) to evaluate the formation of complexes between dendrimers and siRNAs and their stability; (3) to assess the delivery potential of dendrimers by analyzing cellular uptake of dendriplexes; and (4) to determine the ability of dendriplexes to inhibit cancer cell growth, including their combination with the common chemotherapeutic agent 5-fluorouracil (5-FU).

\section{Materials and Methods}

\subsection{Synthesis of Cationic Phosphorus Dendrimers AE2G3, AE2G4}

All manipulations were carried out with standard high vacuum and dry-argon techniques. Conventional ${ }^{1} \mathrm{H},{ }^{13} \mathrm{C}\left\{{ }^{1} \mathrm{H}\right\}$, and ${ }^{31} \mathrm{P}\left\{{ }^{1} \mathrm{H}\right\}$ nuclear magnetic resonance (NMR) spectra were recorded with AV300PAS, AV400PAS, and AV400LIQ spectrometers (Bruker, Fällanden, Switzerland). Numbering used for NMR assignments is shown in Figure 1. The attribution of ${ }^{13} \mathrm{C}-\mathrm{NMR}$ signals has been done using $\mathrm{J}_{\mathrm{mod}}$ and two-dimensional heteronuclear multiple quantum coherence and heteronuclear multiple bond coherence (HMQC and $\mathrm{HMBC}$ ) experiments when necessary. The protonated dendrimers were only characterized by ${ }^{31} \mathrm{P} \mathrm{NMR}$, in order to ascertain the integrity of the structure.

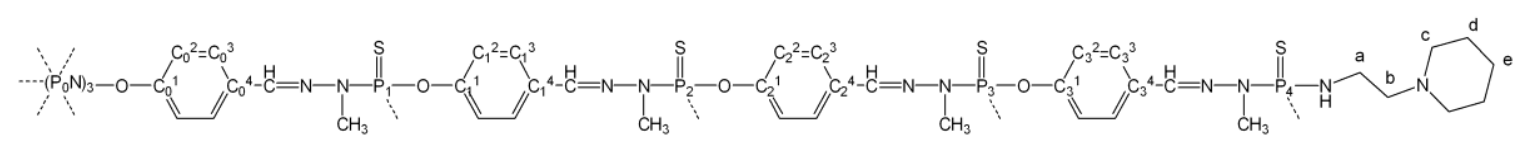

Figure 1. Numbering used for NMR assignments.

Grafting of amines on the periphery of dendrimers. 1.05 equivalents of amine per chloride were added to a solution of $0.4 \mathrm{~g}$ of dendrimer $\mathrm{Gn}(n=3$ or 4$)(0.04 \mathrm{mmol}$ or $0.02 \mathrm{mmol}$, respectively) in distilled THF (tetrahydrofuran, Sigma-Aldrich Chimie, Saint Quentin Fallavier, France; $10 \mathrm{~mL}$ ) at room temperature in the presence of DIPEA ( $N, N$-diisopropylethylamine, Sigma-Aldrich; 2.5 equivalents per chloride, $0.1 \mathrm{mmol}$ ). The resulting mixture was stirred for $3 \mathrm{~h}$ at room temperature, and then volatiles were removed under vacuum. The residue was dissolved in $20 \mathrm{~mL}$ of $\mathrm{CH}_{2} \mathrm{Cl}_{2}$, and then $10 \mathrm{~mL}$ of aqueous solution of potassium carbonate $(1.5 \mathrm{~g})$ was added, followed by the extraction three times with $20 \mathrm{~mL}$ of $\mathrm{CH}_{2} \mathrm{Cl}_{2}$. The organic phases were combined, water traces were removed by drying over magnesium sulfate. The organic phase was filtered through the filter paper, and evaporated to 
dryness under vacuum. The resulting oil was precipitated into $70 \mathrm{~mL}$ of pentane. The resulting white powder (dendrimers AE2Gn ( $n=3$ or 4$)$ ) was recovered by filtration through filter paper and dried under vacuum.

The protonated dendrimers $\mathrm{AE} 2 \mathrm{GnH}+(n=3$ or 4$)$ were obtained by adding a solution of $1.0 \mathrm{M}$ $\mathrm{HCl}$ in diethyl ether $(1.2 \mathrm{~mL}, 1.2 \mathrm{mmol})$ to a solution of dendrimer $(0.4 \mathrm{~g}, 0.026 \mathrm{mmol}$ or $0.13 \mathrm{mmol}$ for G3 and G4, respectively) in distilled THF $(20 \mathrm{~mL})$. The amount of $\mathrm{HCl}$ was calculated to induce theoretically the protonation of $95 \%$ of the terminal nitrogen. The protonated dendrimers precipitated in THF and were simply recovered by filtration.

Dendrimer AE2G3. This compound was isolated as a white powder in $85 \%$ yield. ${ }^{31} \mathrm{P}\left\{{ }^{1} \mathrm{H}\right\} \mathrm{NMR}\left(\mathrm{CDCl}_{3}\right)$ : $\delta 8.5\left(\mathrm{P}_{0}\right), 62.4\left(\mathrm{P}_{1}\right), 62.9\left(\mathrm{P}_{2}\right), 68.1\left(\mathrm{P}_{3}\right) ;{ }^{1} \mathrm{H}-\mathrm{NMR}\left(\mathrm{CDCl}_{3}\right): \delta 1.38\left(\mathrm{~s}, 96 \mathrm{H}, \mathrm{C}_{\mathrm{e}} \mathrm{H}_{2}\right), 1.52\left(\mathrm{~m}, 192 \mathrm{H}, \mathrm{C}_{\mathrm{d}} \mathrm{H}_{2}\right)$, $2.35\left(\mathrm{~s}, 192 \mathrm{H}, \mathrm{C}_{\mathrm{c}} \mathrm{H}_{2}\right), 2.42\left(\mathrm{t}, J=5.9 \mathrm{~Hz}, 96 \mathrm{H}, \mathrm{C}_{\mathrm{b}} \mathrm{H}_{2}\right), 2.90-3.10\left(\mathrm{~m}, 96 \mathrm{H}, \mathrm{C}_{\mathrm{a}} \mathrm{H}_{2}\right), 3.12\left(\mathrm{~d}, J_{H P}=9.5 \mathrm{~Hz}\right.$, $\left.72 \mathrm{H}, \mathrm{CH}_{3} \mathrm{NP}_{3}\right), 3.30\left(\mathrm{~d}, J_{\mathrm{HP}}=10.2 \mathrm{~Hz}, 54 \mathrm{H}, \mathrm{CH}_{3} \mathrm{NP}_{1}, \mathrm{CH}_{3} \mathrm{NP}_{2}\right), 4.04$ (br s, J = 8.6 Hz, $48 \mathrm{H}, \mathrm{NH}$ ), 7.01 $\left(\mathrm{d}, J=7.6 \mathrm{~Hz}, 12 \mathrm{H}, \mathrm{C}_{0}{ }^{3} \mathrm{H}\right), 7.16\left(\mathrm{~d}, J=8.3 \mathrm{~Hz}, 48 \mathrm{H}, \mathrm{C}_{2}{ }^{3} \mathrm{H}\right), 7.21\left(\mathrm{~d}, J=8.3 \mathrm{~Hz}, 24 \mathrm{H}, \mathrm{C}_{1}{ }^{3} \mathrm{H}\right), 7.45(\mathrm{~s}, 24 \mathrm{H}$, $\left.\mathrm{C}_{2}{ }^{4}-\mathrm{CH}\right), 7.64\left(\mathrm{~m}, 60 \mathrm{H}, \mathrm{C}_{0}{ }^{2} \mathrm{H}, \mathrm{C}_{2}{ }^{2} \mathrm{H}\right), 7.69\left(\mathrm{~m}, 42 \mathrm{H}, \mathrm{C}_{1}{ }^{2} \mathrm{H}, \mathrm{C}_{0}{ }^{4}-\mathrm{CH}, \mathrm{C}_{1}{ }^{4}-\mathrm{CH}\right) ;{ }^{13} \mathrm{C}\left\{{ }^{1} \mathrm{H}\right\} \mathrm{NMR}\left(\mathrm{CDCl}_{3}\right)$ :

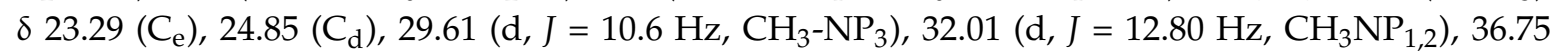
$\left(\mathrm{C}_{\mathrm{a}}\right), 53.24\left(\mathrm{C}_{\mathrm{c}}\right), 57.82\left(\mathrm{~d}, J=8.0 \mathrm{~Hz}, \mathrm{C}_{\mathrm{b}}\right), 119.82-121.00\left(\mathrm{~m}, \mathrm{C}_{0}{ }^{2}, \mathrm{C}_{1}{ }^{2}, \mathrm{C}_{2}{ }^{2}\right), 126.50\left(\mathrm{C}_{2}{ }^{3}\right), 127.21\left(\mathrm{C}_{0}{ }^{3}\right.$, $\left.\mathrm{C}_{1}^{3}\right), 131.08\left(\mathrm{C}_{0}{ }^{1}\right), 131.30\left(\mathrm{C}_{1}{ }^{1}\right), 132.10\left(\mathrm{C}_{2}{ }^{1}\right), 134.33\left(\mathrm{CH}=\mathrm{NNP}_{3}\right), 137.67\left(\mathrm{~d}, J=12.4 \mathrm{~Hz}, \mathrm{CH}=\mathrm{NNP}_{1}\right.$, $\left.\mathrm{CH}=\mathrm{NNP}_{2}\right), 149.50\left(\mathrm{~d}, J=7.0 \mathrm{~Hz}, \mathrm{C}_{1}^{4}, \mathrm{C}_{2}^{4}\right), 150.24\left(\mathrm{~d}, J=7.3 \mathrm{~Hz}, \mathrm{C}_{0}^{4}\right)$.

AE2G3H+. ${ }^{31} \mathrm{P}\left\{{ }^{1} \mathrm{H}\right\} \mathrm{NMR}\left(\mathrm{CD}_{3} \mathrm{OD}\right): \delta 8.15\left(\mathrm{P}_{0}\right), 62.5\left(\mathrm{P}_{1}\right), 62.7\left(\mathrm{P}_{2}\right), 68.1\left(\mathrm{P}_{3}\right)$.

Dendrimer AE2G4. This compound was isolated as a white powder in $95 \%$ yield. ${ }^{31} \mathrm{P}\left\{{ }^{1} \mathrm{H}\right\} \mathrm{NMR}\left(\mathrm{CDCl}_{3}\right)$ : $\delta 62.4\left(\mathrm{P}_{1}, \mathrm{P}_{2}, \mathrm{P}_{3}\right), 68.1\left(\mathrm{P}_{4}\right) ;{ }^{1} \mathrm{H}-\mathrm{NMR}\left(\mathrm{CDCl}_{3}\right): \delta 1.37\left(\mathrm{~s}, 192 \mathrm{H}, \mathrm{C}_{\mathrm{e}} \mathrm{H}_{2}\right), 1.51\left(\mathrm{~m}, 384 \mathrm{H}, \mathrm{C}_{\mathrm{d}} \mathrm{H}_{2}\right), 2.34$ $\left(\mathrm{s}, 384 \mathrm{H}, \mathrm{C}_{\mathrm{c}} \mathrm{H}_{2}\right), 2.40\left(\mathrm{t}, J=6.8 \mathrm{~Hz}, 192 \mathrm{H}, \mathrm{C}_{\mathrm{b}} \mathrm{H}_{2}\right), 2.89-3.09\left(\mathrm{~m}, 192 \mathrm{H}, \mathrm{C}_{\mathrm{a}} \mathrm{H}_{2}\right), 3.12\left(\mathrm{~d}, J_{H P}=9.5 \mathrm{~Hz}\right.$, $\left.144 \mathrm{H}, \mathrm{CH}_{3} \mathrm{NP}_{4}\right), 3.26-3.40\left(\mathrm{~m}, 126 \mathrm{H}, \mathrm{CH}_{3} \mathrm{NP}_{1}, \mathrm{CH}_{3} \mathrm{NP}_{2}, \mathrm{CH}_{3} \mathrm{NP}_{2}\right), 4.03$ (br s, $\left.J=10.0 \mathrm{~Hz}, 96 \mathrm{H}, \mathrm{NH}\right)$, 7.13-7.25 (m, 180H, $\left.\mathrm{C}_{0}^{3} \mathrm{H}, \mathrm{C}_{1}{ }^{3} \mathrm{H}, \mathrm{C}_{2}{ }^{3} \mathrm{H}, \mathrm{C}_{3}{ }^{3} \mathrm{H}\right), 7.45$ (s, 48H, $\left.\mathrm{C}_{3}{ }^{4}-\mathrm{CH}\right), 7.59\left(\mathrm{~m}, 108 \mathrm{H}, \mathrm{C}_{2}{ }^{4}-\mathrm{CH}, \mathrm{C}_{0}{ }^{2} \mathrm{H}\right)$, $7.71\left(\mathrm{~m}, 102 \mathrm{H}, \mathrm{C}_{1}{ }^{2} \mathrm{H}, \mathrm{C}_{2}{ }^{2} \mathrm{H}, \mathrm{C}_{0}{ }^{4}-\mathrm{CH}, \mathrm{C}_{1}{ }^{4}-\mathrm{CH}, \mathrm{C}_{2}{ }^{4}-\mathrm{CH}\right) .{ }^{13} \mathrm{C}\left\{{ }^{1} \mathrm{H}\right\} \mathrm{NMR}\left(\mathrm{CDCl}_{3}\right): \delta 24.12\left(\mathrm{~s}, \mathrm{C}_{\mathrm{e}}\right), 25.61$ $\left(\mathrm{s}, \mathrm{C}_{\mathrm{d}}\right), 30.88\left(\mathrm{~d}, J=9.4 \mathrm{~Hz}, \mathrm{CH}_{3} \mathrm{NP}_{4}\right), 33.08\left(\mathrm{~d}, J=12.7 \mathrm{~Hz}, \mathrm{CH}_{3} \mathrm{NP}_{1}, \mathrm{CH}_{3} \mathrm{NP}_{2}, \mathrm{CH}_{3} \mathrm{NP}_{3}\right), 37.75\left(\mathrm{~s}, \mathrm{C}_{\mathrm{a}}\right)$, $54.27\left(\mathrm{~s}, \mathrm{C}_{\mathrm{c}}\right), 58.83\left(\mathrm{~d}, J=7.7 \mathrm{~Hz}, \mathrm{C}_{\mathrm{b}}\right), 121.61\left(\mathrm{~m}, \mathrm{C}_{0}{ }^{2}, \mathrm{C}_{1}{ }^{2}, \mathrm{C}_{2}{ }^{2}, \mathrm{C}_{3}{ }^{2}\right), 127.62\left(\mathrm{~s}, \mathrm{C}_{3}{ }^{3}\right), 128.27\left(\mathrm{br} \mathrm{s}, \mathrm{C}_{0}{ }^{3}\right.$, $\left.\mathrm{C}_{1}{ }^{3}, \mathrm{C}_{2}{ }^{3}\right), 132.28\left(\mathrm{br} \mathrm{s}, \mathrm{C}_{0}{ }^{4}, \mathrm{C}_{1}{ }^{4}, \mathrm{C}_{2}{ }^{4}\right), 133.14\left(\mathrm{~s}, \mathrm{C}_{3}{ }^{4}\right), 135.66\left(\mathrm{~d}, J=11.3 \mathrm{~Hz}, \mathrm{CH}=\mathrm{NNP}_{4}\right), 138.98$ (br s, $\mathrm{CH}=\mathrm{NNP}_{1}, \mathrm{CH}=\mathrm{NNP}_{2}, \mathrm{CH}=\mathrm{NNP}_{3}, 150.62\left(\mathrm{~d}, J=7.3 \mathrm{~Hz}, \mathrm{C}_{3}{ }^{1}\right), 151.35\left(\mathrm{br} \mathrm{s}, \mathrm{C}_{0}{ }^{1}, \mathrm{C}_{1}{ }^{1}, \mathrm{C}_{2}{ }^{1}\right)$.

AE2G4H+. ${ }^{31} \mathrm{P}\left\{{ }^{1} \mathrm{H}\right\} \mathrm{NMR}\left(\mathrm{CD}_{3} \mathrm{OD}\right): \delta 9.0\left(\mathrm{P}_{0}\right), 62.6$ (br s $\left.\mathrm{P}_{1}, \mathrm{P}_{2}, \mathrm{P}_{3}\right), 69.5\left(\mathrm{P}_{4}\right)$.

\subsection{SiRNAs}

Three pro-apoptotic siRNAs designed for silencing of anti-apoptotic genes from BCL-2 family were synthesized: siBCL-2 (sense 5'-GCUGCACCUGACGCCCUUCtt-3', antisense $5^{\prime}$-GAAGGGCGUCAGGUGCAGCtt- $3^{\prime}$ ) [25], siBCL-xL (sense 5'-CAGGGACAGCAU AUCAGAGtt- $3^{\prime}$, antisense $5^{\prime}$-CUCUGAUAUGCUGUCCCUGtt- ${ }^{\prime}$ ) [25], siMCL-1 (sense 5'-GGAC UUUUAUACCUGUUAU tt- $3^{\prime}$, antisense $5^{\prime}$-AUAACAGGUAUAAAAGUCCtt-3') [29]. The following sequence of Scrambled siRNA was used: 1st strand 5'-ACUCUAGCGGCACCAUCGUGCCtt-3', 2nd strand 5'-GGCACGAUGGUGCCG-CUAGAGUtt-3' [25]. RNA oligonucleotides bear two deoxyribonucleotides at $3^{\prime}$-termini to increase their stability towards exonuclease digestion. Fluorescein-labelled $\left(3^{\prime}\right)$ sense siRNAs strands were also prepared. Oligonucleotides were synthesized using the solid-phase phosphoramidite method on an ASM-800 automated synthesizer (Biosset, Novosibirsk, Russia) from commercially available phosphoramidites (Glen Research, Sterling, VA, USA) according to the protocols optimized for the equipment.

\subsection{Cell Culture}

Human epithelioid cervical carcinoma cell line (HeLa, ATCC) was maintained in DMEM-Glutamax medium (GIBCO-BRL, Paisley, UK) supplemented with $10 \%$ thermally inactivated 
fetal bovine serum (FBS) (GIBCO-BRL), $100 \mathrm{mg} / \mathrm{mL}$ streptomycin and $100 \mathrm{U} / \mathrm{mL}$ penicillin (Sigma Aldrich, Poznań, Poland). Cells were grown in $75 \mathrm{~cm}^{2}$ flasks (Falcon, BD Biosciences, Franklin Lakes, $\mathrm{NJ}$, USA) at $37^{\circ} \mathrm{C}$ in humidified atmosphere with $5 \% \mathrm{CO}_{2}$ and subcultured twice a week after $80 \%$ confluency was reached.

\subsection{Complex Formation Studies}

Dendriplexes formation was investigated to determine the ratios of sustainable association between dendrimers and siRNAs, and the biophysical characteristics of the complexes. Complexation was assessed using dendrimer/siRNA charge ratios (CR) or dendrimer/siRNA molar ratios. CR represents the ratio of total general positive charge of dendrimers (positively charged terminal groups) relative to the general negative charge of siRNAs (phosphates) in a sample, being calculated as follows:

$$
C R=\frac{C_{D} \times Z_{D}}{C_{s i R N A} \times Z_{s i R N A}}=M R \times \frac{Z_{D}}{Z_{s i R N A}},
$$

where $C_{D}$-final concentration of dendrimer in a sample, $Z_{D}$-charge of a single dendrimer molecule, $C_{\text {SiRNA }}$-final concentration of siRNA in a sample, $Z_{s i R N A}$ - charge of a single siRNA molecule, $M R$-dendrimer/siRNA molar ratio.

Circular Dichroism. Circular dichroism (CD) was measured in the far-UV region using a J-815 CD spectrometer (Jasco, Tokyo, Japan). The experiments were done in $10 \mathrm{mM}$ sodium phosphate buffer, $\mathrm{pH}$ 7.4. The concentration of the siRNAs was $1 \mu \mathrm{M}$. CD spectra were obtained in the range between 300 and $200 \mathrm{~nm}$. Quartz $0.5 \mathrm{~cm}$ path length cells (Hellma, Jena, Germany) were used for all CD experiments. The recording parameters were: scan speed $50 \mathrm{~nm} / \mathrm{min}$, response time $2 \mathrm{~s}$, slit width 1 , bandwidth $1.0 \mathrm{~nm}$, and step resolution $1 \mathrm{~nm}$. CR-dependent measurements were taken starting from naked siRNA with a sequential increase of dendrimer concentration in the samples. Three scans were run for each naked siRNA and for each dendrimer/siRNA CR. The mean residue ellipticity, $\theta$, expressed as $\mathrm{cm}^{2} \mathrm{dmol}^{-1}$, was calculated.

Measurement of zeta potential. Particle surface potentials were measured by phase analysis light scattering (PALS), using a Malvern Instruments Zetasizer Nano-ZS (Malvern, Worcestershire, UK). The concentration of the siRNAs was $0.5 \mu \mathrm{M}$. Capillary plastic cells DTS1061 (Malvern) were used to measure the electrophoretic mobility of the samples in an applied electric field starting from naked siRNA with a sequential increase of dendrimer concentration in the samples. Ten to 15 measurements of zeta potential were made and averaged for each naked siRNA and for each dendrimer/siRNA CR. The Helmholtz-Smoluchowski equation in the Malvern software version 7.02 was used to calculate the zeta potential values.

Gel Electrophoresis. Agarose gel electrophoresis was used to examine the formation of complexes between dendrimers and siRNAs, since positively charged dendrimers prevent negatively charged siRNA from migrating in an electric field. Gel electrophoresis was used also to check whether dendrimers protect siRNA from enzymatic degradation.

Dendrimers were complexed with fluorescein-labeled siBcl-xL $(1.5 \mu \mathrm{M})$ in different molar ratios. Complexes were incubated for $10 \mathrm{~min}$ at room temperature in $10 \mathrm{mM}$ Na-phosphate buffer, $\mathrm{pH}$ 7.4. Complex formation was assessed by the retardation of migration of the fluoresceinated siRNAs during electrophoresis for $35 \mathrm{~min}$ at $60 \mathrm{~mA}$ in a 3\% agarose gel using GelRed stain (Biotium Inc., Hayward, CA, USA). After electrophoresis, the gel was visualized using UV light, and a digital photograph of the stained gel was taken.

To evaluate the protective effect of dendrimers from siRNA degradation, dendrimer/siRNA complexes at MR 2:1 and siRNA alone were treated with RNAse A $(1.25 \mu \mathrm{g} / \mathrm{mL})$ for $45 \mathrm{~min}$ at $37^{\circ} \mathrm{C}$. Heparin $(0.082 \mathrm{mg} / \mathrm{mL})$ was added to the samples and incubated on ice for 5 min to check whether siRNA was protected from digestion by RNAse A. 
Atomic Force Microscopy studies of dendriplexes. Dendriplexes were prepared by mixing solutions of siRNA $(1 \mu \mathrm{M})$ and dendrimer at CR 10:1. An aliquot of dendriplex solution was deposited on to a mica slide for 1-2 min. The slide was washed 3 times with deionized water and dried.

Scanning in a tapping mode involved a Multimode8 atomic force microscope (Bruker) with NSG10-DLC cantilevers and a tip curvature radius of 1-3 nm (NT-MDT, Zelenograd, Russia) at a scanning rate of $3 \mathrm{~Hz}$. Images were processed using Gwyddion software (version 2.36, Czech Metrology Institute, Brno, Czech Republic).

\subsection{Cellular Uptake}

Flow cytometry. To investigate the internalization of dendriplexes into HeLa cells, we used siRNAs conjugated with fluorescein (green fluorescence). HeLa cells were seeded on 12-well plates $24 \mathrm{~h}$ prior treatment at 200,000 cells/well density in $1 \mathrm{~mL}$ complete medium. Dendrimer/siRNA CR 10:1 was used in cellular uptake experiments. Lipofectamine 2000 (Invitrogen, Carlsbad, CA, USA), a common transfection agent, was used as a reference. Dendriplexes for treatment were formed in phosphate buffered saline (PBS, $150 \mathrm{mM}$, pH 7.4), complex formation with Lipofectamine 2000 was carried out according to the manufacturer's protocol, except excluding serum and antibiotics from the medium. Pro-apoptotic siRNAs were delivered as a cocktail that included equal shares of siRNAs $(1 / 3$ for each siRNA). The final concentration of siRNA was $100 \mathrm{nM}$. After 3 and $24 \mathrm{~h}$ incubation with dendriplexes, cells were trypsinized, washed twice with PBS and analyzed for fluorescence by measurements in a Beckman-Coulter Gallios flow cytometer (Beckman-Coulter, Brea, CA, USA) with the acquisition of 15,000 analyzable events. Before the second wash with PBS, cell pellet was treated with $50 \mu \mathrm{L}$ acidic glycine solution ( $50 \mathrm{mM}, \mathrm{pH} 3.2)$ for $30 \mathrm{~s}$ with gentle pipetting.

Confocal microscopy. HeLa cells were seeded at $2 \times 10^{5}$ cells $/ \mathrm{mL}$ per well in 6-well plates containing thin glass coverslips in $1 \mathrm{~mL}$ of complete medium $24 \mathrm{~h}$ prior treatment. The cells were treated with a PBS-based solution of dendriplexes bearing fluorescein labeled siBcl-xL, the final siRNA concentration being $100 \mathrm{nM}, \mathrm{CR}$ 10:1. After $3 \mathrm{~h}$ incubation, the cells were washed twice with $0.1 \%$ bovine serum albumin (BSA) containing PBS and fixed by $10 \%$ formalin solution (5 $\mathrm{min}$, room temperature (RT)). To obtain permeabilized cells we used $0.1 \%$ Triton-X solution for $5 \mathrm{~min}$, RT. Cell labeling solutions were then added to each sample; two were used: (1) DAPI (4',6-diamidino-2' - -phenylindole dihydrochloride; Sigma Aldrich, Poznań, Poland) emits blue fluorescence when bound to double-stranded DNA, mostly seen in nuclei; (2) propidium iodide (PI, Life Technologies, Carlsbad, CA, USA) emits in red spectrum region after intercalation into double-stranded DNA or RNA. After staining DNA with DAPI $(250 \mu \mathrm{L}$ of $300 \mathrm{nM}$ solution, $5 \mathrm{~min}$, RT with following washing), staining with PI ( $250 \mu \mathrm{L}$ of $25 \mu \mathrm{M}$ solution, $5 \mathrm{~min}$, RT with following wash) provide cytoplasm visualization as it stains all endogenous double-stranded nucleic acids. The maximum emission wavelengths were $565 \mathrm{~nm}$ and $454 \mathrm{~nm}$, respectively, for PI and DAPI. Internalization of fluoresceinated siRNA into the cells was detected using high-performance laser-based confocal imaging system (Leica TCS SP8, Mannheim, Germany) at a magnification of 10,000×.

\subsection{Assessment of Cancer Cell Growth Inhibition}

The cancer cell growth inhibition caused by dendrimers, siRNAs, 5-FU and their combinations was assessed using MTT cytotoxicity assay based on Mossman et al. [31] with 3-[4,5-2-yl]-2-5-diphenyltetrazolium bromide (Sigma-Aldrich, Poznań, Poland). HeLa cells were seeded at $1 \times 10^{5}$ cells $/ \mathrm{mL}$ in $100 \mu \mathrm{L}$ in 96-well plates (10,000 cells/well) $24 \mathrm{~h}$ prior treatment. After cell adhesion, $10 \mu \mathrm{L}$ PBS-based solution containing investigated factor were added to each well, and the cells were incubated for $72 \mathrm{~h}$. After incubation, medium was discarded from plates, $0.5 \mathrm{mg} / \mathrm{mL}$ MTT in PBS, pH 7.4 was added to each well and the plates were incubated for $4 \mathrm{~h}$ in growing conditions. After this time, the MTT solution was discarded, $100 \mu \mathrm{L}$ dimethyl sulfoxide (DMSO) was added to each well to dissolve the formazan crystals. Absorbance measurements were carried out with a PowerWave XS microplate spectrophotometer (BioTek Instruments, Winooski, VT, 
USA) at $\lambda_{\mathrm{abs}}=570 \mathrm{~nm}$ and $\lambda_{\mathrm{abs}}=720 \mathrm{~nm}$. Viability of cells (\%) was calculated from $\mathrm{D}_{570}-\mathrm{D}_{720}$ values relatively to the averaged $D_{570}-D_{720}$ value in untreated controls (10 $\mu \mathrm{L}$ PBS added to the wells).

Cytotoxicity of dendrimers. AE2G3 and AE2G4 dendrimers were added to cells at concentrations from 0.05 to $5 \mu \mathrm{M}$. IC50s were calculated using GraphPad Prism 7 Software (version 7.0.3, GraphPad Software, Inc., San Diego, CA, USA).

Cytotoxicity of dendriplexes. AE2G3 and AE2G4 dendrimers were complexed with the cocktail of pro-apoptotic anticancer siRNAs (siBCL-2, siBCL-xL, siMCL-1) at CR 10:1 in PBS within 15 min, and the complexes transferred to cells on plates. The final concentration of siRNAs was from 25 to $100 \mathrm{nM}$ for AE2G3 dendrimers and $100 \mathrm{nM}$ for AE2G4 dendrimers. The cocktail included equal shares of siRNAs (1/3 of each siRNA). For example, $100 \mathrm{nM}$ cocktail included $33.3 \mathrm{nM}$ of siMCL-1, $33.3 \mathrm{nM}$ of siBCL-2 and $33.3 \mathrm{nM}$ of siBCL-xL. Final concentrations of dendrimers used for the delivery of siRNAs are shown in Table 1. Cytotoxicity of naked siRNAs (without dendrimers) at $100 \mathrm{nM}$ was also tested.

Table 1. Final concentrations of dendrimers used for delivery of siRNAs.

\begin{tabular}{cccc}
\hline \multirow{2}{*}{ Concentration of siRNA } & \multirow{2}{*}{ Charge Ratio } & \multicolumn{2}{c}{ Dendrimer } \\
\cline { 2 - 4 } & & AE2G3 & AE2G4 \\
\hline $100 \mathrm{nM}$ & $10: 1$ & $0.88 \mu \mathrm{M}$ & $0.44 \mu \mathrm{M}$ \\
\hline $50 \mathrm{nM}$ & $10: 1$ & $0.44 \mu \mathrm{M}$ & - \\
\hline $25 \mathrm{nM}$ & $10: 1$ & $0.22 \mu \mathrm{M}$ & - \\
\hline & $5: 1$ & $0.11 \mu \mathrm{M}$ & - \\
\hline
\end{tabular}

Cytotoxicity of dendriplexes in combination with 5-FU. To evaluate the combined effects of exposure to siRNA/dendrimer complexes and 5-FU (Sigma-Aldrich), slightly toxic final concentrations of 5-FU $(2.5 \mu \mathrm{M})$ and the cocktail of pro-apoptotic siRNAs $(25 \mathrm{nM})$ were chosen. The siRNA cocktail was delivered be means of the AE2G3 dendrimer.

Complexes of siRNAs and dendrimers were formed in PBS (150 mM, pH 7.4) within a $15 \mathrm{~min}$ incubation to obtain dendrimer/siRNA charge ratios 5:1 or 10:1 at $25 \mathrm{nM}$ of siRNA concentration; $5-\mathrm{FU}$ was then given to the solution and the mixture was added to the cells on plates. Complexes with scrambled siRNA, dendrimers and 5-FU per se were used as controls for comparison.

\section{Results}

\subsection{Synthesis of Cationic Phosphorus Dendrimers AE2G3, AE2G4}

The amino-terminated dendrimers (Table 2) were obtained by grafting of 1-(2-aminoethyl)-piperidine onto the periphery of precursor $\mathrm{P}(\mathrm{S}) \mathrm{Cl}_{2}$-terminated phosphorus dendrimers of third and fourth generation in the presence of DIPEA as a base. The dendrimeric precursors were obtained by growing from a cyclotriphosphazene core as described in [32].

Table 2. Structures of the cationic phosphorous dendrimers.

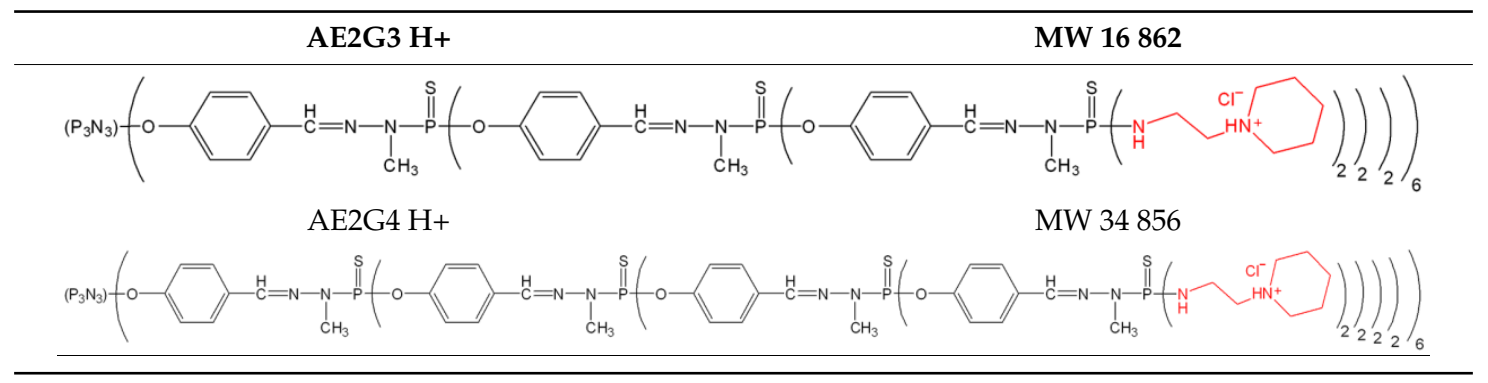


The reaction of primary amine with $\mathrm{P}(\mathrm{S}) \mathrm{Cl}_{2}$ fragments was followed by the shift of the signals of the peripheral phosphorous atoms in dendrimer from 62.8 to $68.1 \mathrm{ppm}$. An intermediate signal at $71.3 \mathrm{ppm}$ corresponding to the monosubstitution at phosphorous atom was also observed in the first hour of reaction; however, it disappeared later. The neutral amino-terminated dendrimers were obtained quantitatively, isolated with high yields ( $>90 \%$ ) after work-up, and characterized by ${ }^{1} \mathrm{H},{ }^{13} \mathrm{C}$ and ${ }^{31} \mathrm{P}$ NMR. The water-soluble cationic dendrimers were obtained by protonation of neutral ones with $\mathrm{HCl}$ in THF and characterized only by ${ }^{31} \mathrm{P}$ NMR to prove the integrity of structure.

\subsection{Complex Formation Studies}

Circular dichroism measurements showed changes in the secondary structure of siBCL-2, siBCL-xL, siMCL-1 and Scrambled siRNA after addition of AE2G3 and AE2G4 dendrimers. Mean residue ellipticity at $\lambda=210 \mathrm{~nm}$ peak of all siRNAs reached a value close to 0 , with the formation of saturated complexes at $C R \geq 5: 1$ for both dendrimers (Supporting information, Figure S1). Zeta potential measurements indicated the formation of positively charged complexes giving a surface potential of 15-20 $\mathrm{mV}$ with saturation point near CR 5:1 for dendrimers of both generations (Supporting information, Figure S2). Agarose gel electrophoresis showed that dendrimers fully retarded the mobility of fluorescein-labelled siRNAs in applied electric field when complexed with siRNA at dendrimer/siRNA molar ratio of $\geq 1.5: 1$ for both generations of dendrimers (Supporting information, Figure S3). A molar ratio of 1.5:1 corresponds to CR 1.8:1 for AE2G3 and CR 3.6:1 for AE2G4 dendrimers. Dendrimers protected siRNA from degradation by RNAse A. (Supporting information, Figure S4). In the presence of heparin, complexes partially released siRNA (Supporting information, Figure S5). AFM images showed that dendriplexes are compact spherical or elliptical particles with an average size of $\sim 50 \mathrm{~nm}$ for both generations of dendrimers (Supporting information, Figure S6).

\subsection{Cellular Uptake}

Dendrimer mediated cellular uptake of $100 \mathrm{nM}$ fluorescein-labelled pro-apoptotic siRNAs delivered as a cocktail at the dendrimer/siRNA CR of 10:1 was examined by flow cytometry on HeLa cells (Figure 2). Scrambled siRNA was taken as a single siRNA control. The percent of fluorescein-positive cells was calculated.

Naked siRNAs did not internalize into HeLa cells. In combination with dendrimers, fluorescein-labelled siRNAs were detected in $85.3 \pm 12.8 \%$ and $85.6 \pm 12.8 \%$ of cells in $3 \mathrm{~h}$ for AE2G3- and AE2G4-based complexes, respectively. After $24 \mathrm{~h}$, uptake was $91.6 \pm 2.9 \%$ for AE2G3- and $92.4 \pm 4.6 \%$ for AE2G4-based dendriplexes and no statistically significant difference was found with $3 \mathrm{~h}$ incubation. The internalization of $100 \mathrm{nM}$ single scrambled siRNA was $89.9 \pm 12.3 \%$ for AE2G3 and $96.5 \pm 5.4 \%$ for AE2G4 dendrimer after $3 \mathrm{~h}$ incubation, and $91.8 \pm 7.38 \%$ for AE2G3 and $97.4 \pm 0.26 \%$ for AE2G4 after $24 \mathrm{~h}$. There was no significant difference in the internalization rate of scrambled siRNA compared with the cocktail of pro-apoptotic siRNAs, neither at $3 \mathrm{~h}$ nor $24 \mathrm{~h}$ incubation for both dendrimers.

The percent of HeLa cells with internalized by means of Lipofectamine 2000 pro-apoptotic siRNAs delivered as the cocktail was $34.5 \pm 16.3 \%$ and $47.5 \pm 18.8 \%$ after $3 \mathrm{~h}$ and $24 \mathrm{~h}$ incubation time, respectively. The difference between AE2G3 and AE2G4 dendrimers was statistically significant (Newman-Keuls post hoc test, $p<0.01$ ) for both dendrimers after 3 and $24 \mathrm{~h}$ incubation. The internalization profile of Scrambled siRNA was identical to the cocktail; there were no significant differences, irrespective of dendrimer generation and incubation time.

Dendrimer mediated uptake of fluorescein-labelled siRNAs was confirmed by confocal microscopy studies after $3 \mathrm{~h}$ incubation with $100 \mathrm{nM}$ siBCL-xL-Flu delivered to cells at CR 10:1. Green fluorescent areas were found near the cytoplasmic membrane and deeper in the cytosol. Confocal microscopy images are shown in the Supporting information, Figure S7.

Summing up the data, AE2G3 and AE2G4 dendrimers allow high siRNA uptake ( $>80 \%)$ by HeLa cells being more effective than in the case of Lipofectamine 2000 under standard cell growth conditions. 

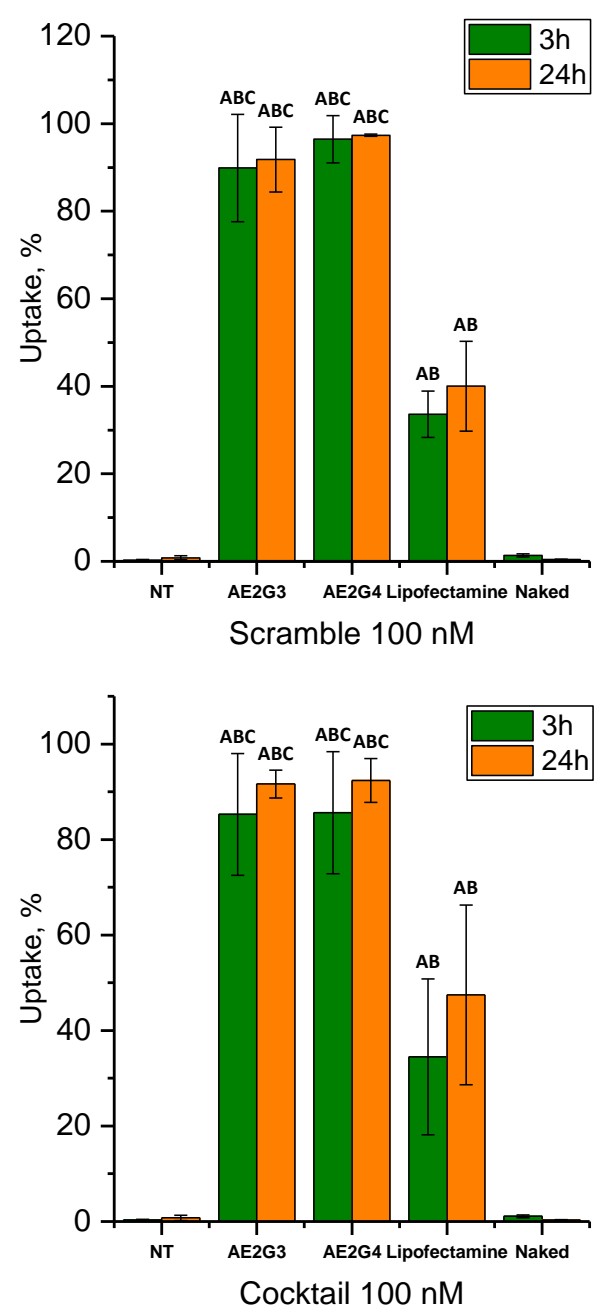

Figure 2. Cellular uptake of $100 \mathrm{nM}$ scrambled siRNA (top panel) and $100 \mathrm{nM}$ pro-apoptotic siRNA cocktail (1/3 siBCL-2, 1/3 siBCL-xL, 1/3 siMCL-1; (bottom panel) mediated by AE2G3, AE2G4 dendrimers and Lipofectamine 2000 by HeLa cells after 3 and $24 \mathrm{~h}$ incubation. Dendrimer/siRNA charge ratio 10:1. A-significant difference to untreated cells (Newman-Keuls post hoc test), $p<0.01$. B-significant difference to naked siRNA (Newman-Keuls post hoc test), $p<0.01$. C-significant difference to Lipofectamine 2000 based complexes, (Newman-Keuls post hoc test), $p<0.01$. Data are presented as Mean \pm Standard Deviation. $n=4$ to 6 .

\subsection{Assessment of Cancer Cell Growth Inhibition}

\subsubsection{Cytotoxicity of Dendrimers}

The cytotoxicity of AE2G3 and AE2G4 dendrimers on HeLa cells was determined to assess "safe" concentration ranges for siRNA delivery (Figure 3). Viability decreased with increasing concentrations of dendrimers. AE2G3 was more toxic than AE2G4 (ANOVA comparison of two curves, $p<0.0001$ ). IC50 for AE2G3 was $1.16 \pm 0.21 \mu \mathrm{M}$ vs. $3.46 \pm 0.63 \mu \mathrm{M}$ for AE2G4. The expected concentrations that could be used for gene delivery in vitro without removal of the dendrimer from medium within $72 \mathrm{~h}$ might have caused no more than $20 \%$ growth inhibition and are up to $0.5 \mu \mathrm{M}$ for AE2G3 and $1 \mu \mathrm{M}$ for AE2G4. 


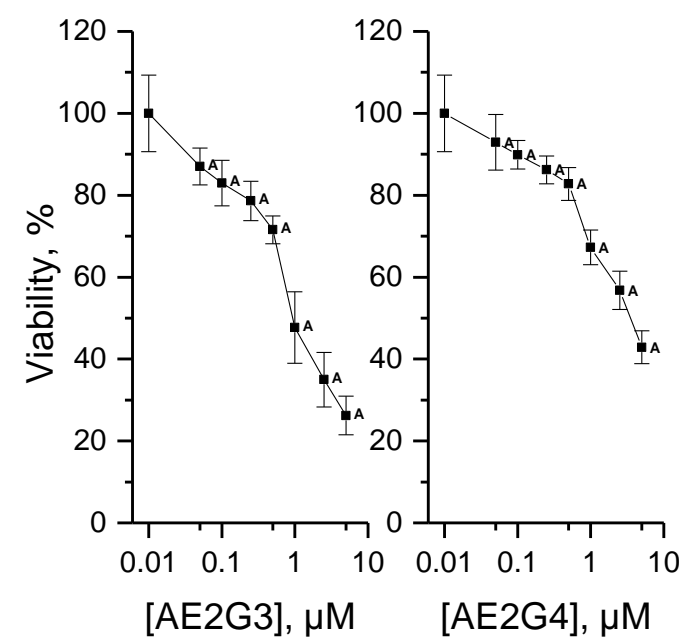

Figure 3. Viability of HeLa cells exposed to AE2G3 and AE2G4 dendrimers for $72 \mathrm{~h}$. The point $0.01 \mu \mathrm{M}$ corresponds to untreated control (log scale). Data are presented as Mean \pm Standard Deviation. A-significant difference to untreated control (Newman-Keuls post hoc test), $p<0.001$. $n$ for each concentration $=18, n$ of untreated control $=72$.

\subsubsection{Cytotoxicity of Dendriplexes}

The impact of dendriplexes bearing either the cocktail of pro-apoptotic siRNAs or scrambled siRNA on HeLa cell viability was investigated using the MTT assay (Figure 4). Cells treated with siRNAs not complexed with dendrimers did not show any difference in viability as compared to untreated cells (data not presented). The AE2G3 dendrimer at the concentrations used to deliver siRNAs was slightly toxic as the viability of HeLa cells in dendrimer control samples decreased down to $70.24 \pm 6.52 \%$ for $0.88 \mu \mathrm{M}$ AE2G3, which was needed for delivery of $100 \mathrm{nM}$ siRNA using CR of 10:1.
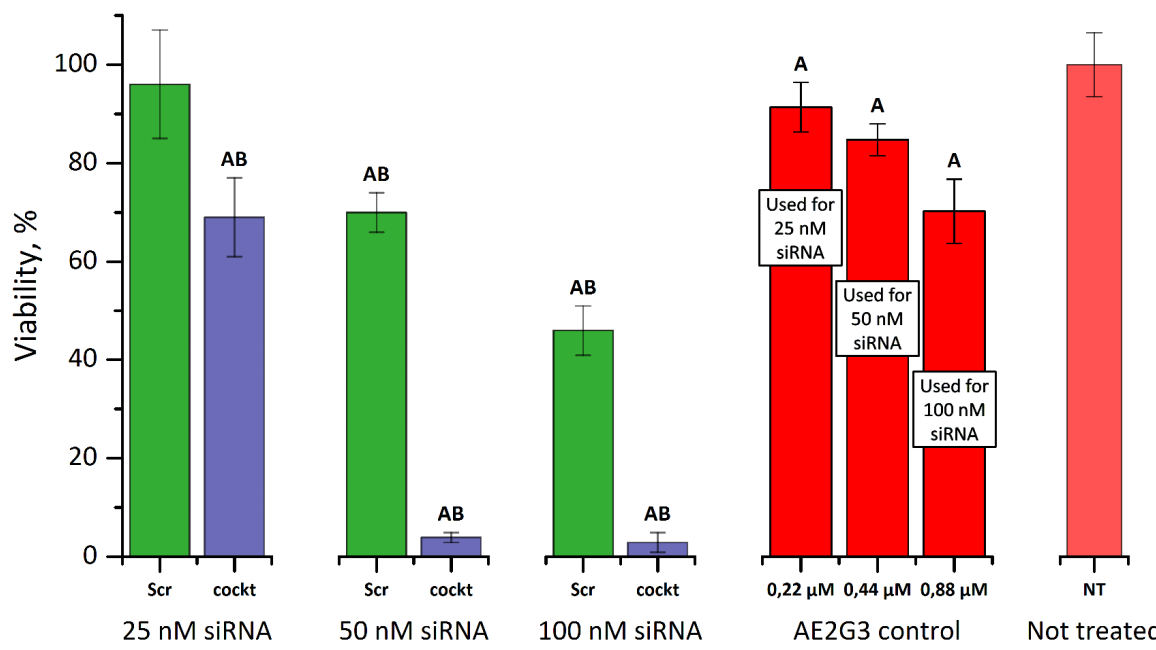

Figure 4. Viability of HeLa cells exposed to AE2G3/pro-apoptotic siRNAs dendriplexes formed at dendrimer/siRNA charge ratio 10:1 for $72 \mathrm{~h}$. A-significant difference to untreated cells (Dunnett test), $p<0.001$. B-significant difference to relevant concentration of dendrimer, used to form dendriplex (Dunnett test), $p<0.001$. Data are presented as Mean \pm Standard Deviation. $n$ for each group was ranged from 18 to $36, n$ of untreated control $=315$.

The viability of HeLa cells decreased with increasing levels of siRNA. Delivered by AE2G3 dendrimer $25 \mathrm{nM}$ pro-apoptotic siRNAs cocktail decreased viability down to $67.8 \pm 10.3 \%$, whereas 50 and $100 \mathrm{nM}$ of siRNA cocktail caused almost complete cell death after $72 \mathrm{~h}$ incubation. Scramble based 
dendriplexes did not affect viability at $25 \mathrm{nM}$ siRNA; however, they caused substantial decrease in viability of cells, down to $69.5 \pm 3.7 \%$ and $46.4 \pm 4.7 \%$ for 50 and $100 \mathrm{nM}$, respectively.

Paired comparisons with $t$-tests showed significant difference in the viability of HeLa cells treated with scrambled siRNA compared with the cocktail of pro-apoptotic siRNAs regardless the concentration $(p<0.001)$, which allows us to conclude that pro-apoptotic siRNAs delivered by AE2G3 dendrimers reduce viability more efficiently than using non-specific siRNA. However, the sequence of scrambled siRNA could complementarily match the mRNA sequences of other vitally important genes, thereby manifesting in reduced viability of cells treated with scramble-bearing complexes.

The difference in viability of HeLa exposed to AE2G3- and AE2G4-based complexes containing $100 \mathrm{nM}$ of the cocktail of pro-apoptotic siRNAs is shown in Figure 5. The viability of cells treated with AE2G4 at the concentration used for delivery of siRNA decreased down to $85.3 \pm 4.9 \%$. A significantly different decrease in viability than caused by dendrimer per se was observed in cells treated with the cocktail: down to $59.9 \pm 6.6 \%$. The cytotoxic effect of AE2G3-based dendriplexes was significantly higher than that of AE2G4-based dendriplexes $(p<0.001, t$-test) in scrambled siRNA and cocktail-treated cells.

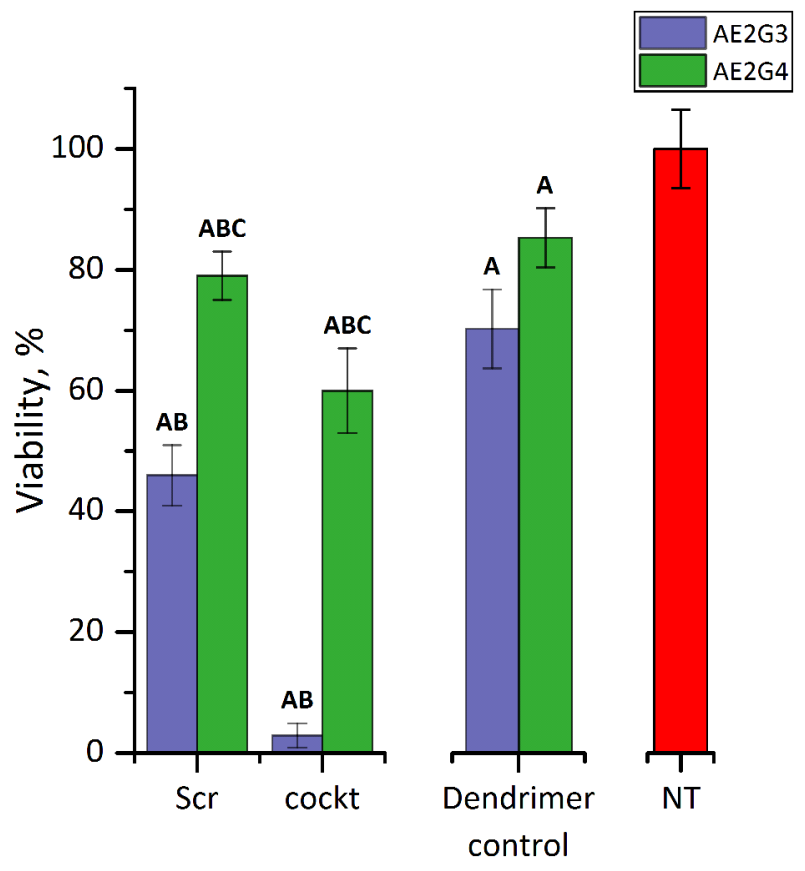

Figure 5. Viability of HeLa cells exposed to AE2G3/AE2G4 based dendriplexes used to deliver $100 \mathrm{nM}$ pro-apoptotic siRNAs at dendrimer/siRNA charge ratio 10:1 for $72 \mathrm{~h}$. A-significant difference to untreated cells (Dunnett test), $p<0.001$. B-significant difference to relevant concentration of dendrimer, used to form dendriplex (Dunnett test), $p<0.001$. C-significant difference to relevant dendriplex based on AE2G3 dendrimers ( $t$-test), $p<0.001$. Data are presented as Mean \pm Standard Deviation. $n$ for each group was ranged from 18 to $36, n$ of untreated control $=315$.

\subsubsection{Cytotoxicity of Dendriplexes in Combination with 5-FU}

For combination with 5-FU, AE2G3-based complexes bearing $25 \mathrm{nM}$ of pro-apoptotic siRNAs were used. The $2.5 \mu \mathrm{M}$ concentration of 5-FU was chosen on the basis of its cytotoxicity profile in order to have the opportunity to assess combined effects (Figure 6), and decreased the viability of HeLa cells down to $61.1 \pm 10.5 \%$. Dendrimers per se were slightly toxic at concentrations utilized for delivery (Figure 7). Complexes bearing scrambled siRNA were not different in their cytotoxic effects from untreated controls at both charge ratios. A slight decrease in viability of cocktail-treated cells was seen, with dendriplexes being more toxic at CR 10:1 in comparison to CR 5:1. The combination of 
dendriplexes with 5-FU led to a significant decrease of viability compared with all the investigated dendriplexes not given the chemotherapeutic (set of $t$-tests, $p<0.001$ ).

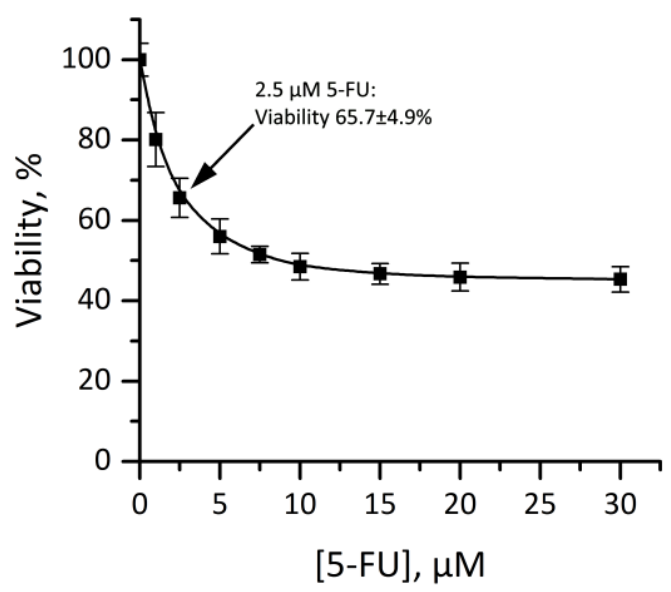

Figure 6. Cytotoxicity of 5-FU towards HeLa cells after $72 \mathrm{~h}$ incubation. The concentration marked with an arrow was chosen for combination experiments with dendriplexes. Data are presented as Mean \pm Standard Deviation. $n$ for each concentration $=18, n$ of untreated control $=72$.

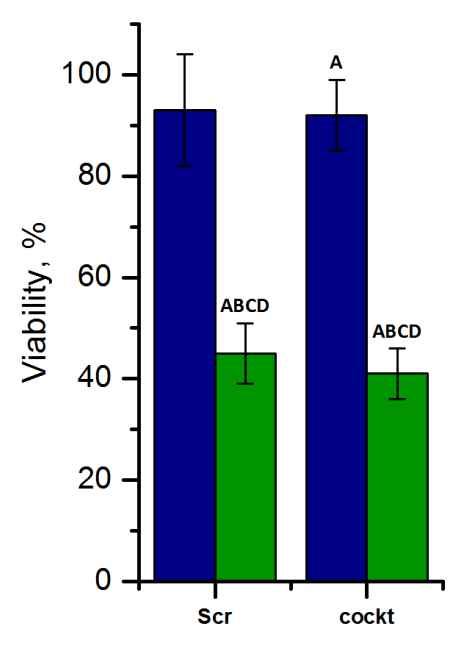

CR 5:1

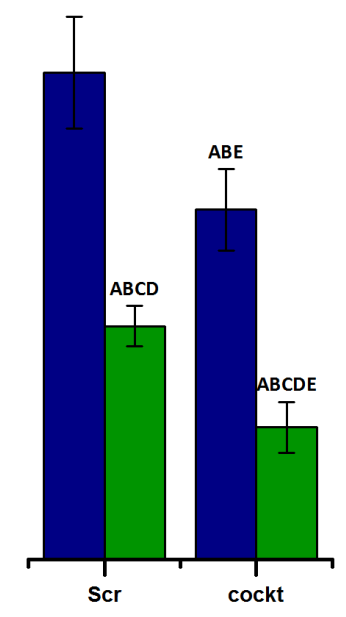

CR 10:1

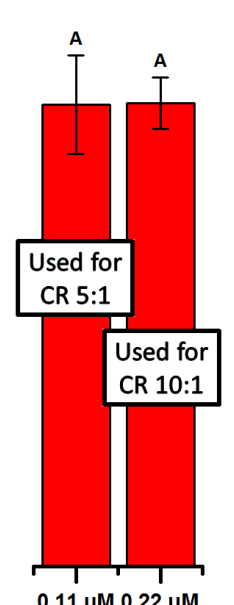

$0,11 \mu \mathrm{MM} 0,22 \mathrm{uM}$

AE2G3 control
Dendriplex

Dendriplex + 5-FU

Figure 7. Differences in the viability of HeLa cells exposed to AE2G3/pro-apoptotic siRNAs dendriplexes formed at dendrimer/siRNA charge ratios of 5:1 and 10:1 with $25 \mathrm{nM}$ siRNA in combination with $2.5 \mu \mathrm{M}$ 5-FU. A-significant difference to untreated cells (Dunnett test), $p<0.001$. $\mathrm{B}$ - significant difference to relevant concentration of dendrimer, used to form dendriplex (Dunnett test), $p<0.001$. C - significant difference to $2.5 \mu \mathrm{M} 5$-FU (Dunnett test), $p<0.001$. D-significant difference to relevant dendriplex w/o 5-FU ( $t$-test), $p<0.001$. E-significant difference to relevant dendriplex formed at CR 5:1 ( $t$-test), $p<0.001$. Data are presented as Mean \pm Standard Deviation. $n$ of untreated control $=315, n$ of $5-\mathrm{FU}$ group $=139$, for all other groups $-n$ was ranged from 18 to 36 .

\section{Discussion}

The search for the new delivery vehicles for siRNAs remains one of the priorities in the field of RNAi-based gene therapy against cancers. In this original work, we describe a new delivery system on the basis of surface-modified phosphorus dendrimers that can be applied for the purpose of effective inhibition of tumor cell growth using a cocktail of pro-apoptotic siRNAs (siBCL-2, siBCL-xL, siMCL-1). 
Cationic phosphorus dendrimers are prospective carriers for siRNA. However, just limited data on their interactions with siRNA and efficiency of delivery are published $[17,19,20]$. The first example of cationic phosphorus dendrimers contained diethylamine groups on the periphery [13]. These dendrimers were quite efficient in nucleic acid delivery but quite toxic. The next generation cationic phosphorus dendrimers bore voluminous cations on the periphery [18] that permitted to weaken the interaction between dendrimer and nucleic acid, thus facilitating the release of the latter. Indeed, one of the new cationic dendrimers, namely the one with pyrrolidine groups on the periphery, demonstrated better transfection efficiency, as compared to the first one. Thus, dendrimers bearing voluminous cations on the periphery are better for the transfection. This observation provides a vector for the rational design of the dendrimer-based pharmaceuticals [33,34] according to the critical parameters of the molecular design [35-37].

In the present work, we synthesized new phosphorus-containing dendrimers (generations 3 and 4) bearing piperidine cations on the periphery. Since piperidine is the most voluminous cation among the described above, we could expect higher efficiency of nucleic acid delivery and release in comparison with the analogs.

The newly synthesized AE2G3 and AE2G4 dendrimers showed excellent properties in binding to pro-apoptotic siRNAs, confirmed by three biophysical methods (circular dichroism, zeta-potential, gel electrophoresis), which consistently showed formation of sustainable complexes at $\geq 5$-fold excess of dendrimers positive charges over negative charges of siRNAs. The siRNA binding profile of piperidine-terminated dendrimers differed from that of diethylamine-terminated CPD in gel electrophoresis studies $[19,20]$. Although they have comparable size and the same amount of positively charged groups, AE2 dendrimers of 3rd and 4th form stable dendriplexes at lesser dendrimer/siRNA molar ratios ( $\geq 1.5$ for both generations) compared to the same generations of diethylamine-terminated CPD ( $\geq 6$ for both generations). This indicates better binding properties of piperidine-terminated dendrimers and allows to reduce the necessary amount of dendrimers for transfection purposes. AE2 dendrimers can protect siRNA against enzymatic degradation, and the AFM-determined size of dendriplexes leads us to be confident of their usefulness as a nano-scaled drug delivery system.

These novel dendrimers provide high siRNA uptake by tumor cells. The delivery of siRNAs by means of piperidine-terminated CPD is more effective than that by Lipofectamine 2000 in standard cell growth conditions. Thus, new opportunity for rapid and effective siRNA transfection of cancer cells for the development of gene-based drugs can be offered by using of AE2 dendrimers as an alternative to one of the most common transfection reagents. HeLa cells tend to internalize the cocktail at the same efficacy as homogenous siRNAs, which indicates uniformity of the mixture of the investigated siRNAs.

Higher cytotoxicity of AE2G3 compared with AE2G4 dendrimer on HeLa cells can be explained by non-specific intracellular interactions with components of the cytosol. Such a dendrimer of generation 3 probably has a more flexible structure with better accessibility of internal groups to cellular content. It should be noted that non-generation dependent cytotoxicity occurred with some other dendrimeric structures [38,39].

An ideal delivery vehicle should be non-toxic [40], but, in the case of pro-apoptotic siRNA-based therapy of cancer, the slight toxicity of AE2G3 dendrimer could be useful, enhancing an anti-tumor effect by initially triggering apoptosis, with subsequent RNAi-based downregulation of anti-apoptotic genes. Moreover, nano-sized compounds tend to accumulate selectively in the solid tumor tissues due to the enhanced permeability and retention (EPR) effect, lowering the risks of side effects for non-tumor tissues [41]. Alternatively, the implementation of dendrimer-mediated active targeting strategies, i.e., dendrimer surface modification by tumor specific ligands [41], promises further improvement of AE2 dendrimers' potency in anti-cancer therapy.

While AE2G3- and AE2G4-based dendriplexes have identical internalization profiles, the cytotoxic effects of AE2G3-based dendriplexes are much more pronounced. Apparently, the AE2G3 dendrimer provides better release of siRNA from complexes after their internalization. The size of dendrimers probably plays an important role in the intracellular release of genetic material, as an extended 
hydrophobic backbone of the generation 4 dendrimer might have greater contribution to siRNA retention than in case of AE2G3.

Regarding the significant decrease of viability of HeLa cells after treatment with 50 and $100 \mathrm{nM}$ scrambled siRNA delivered by means of the AE2G3 dendrimer, we assume unintended off-target effects [42] due probably to partial complementary matching of the scrambled siRNA sequence to the mRNA sequences of other vitally important genes in HeLa cells. For instance, BLAST (Basic Local Alignment Search Tool provided by the U.S. National Center for Biotechnology Information, NCBI) search revealed partial complementarity (13 nucleotides) of Scrambled siRNA sequences to several transcripts of genes coding metabolically active proteins, such as 5-methyltetrahydrofolate-homocysteine methyltransferase (involved in the metabolism of essential amino acids), kinesin family member 3B (takes part in chromosome movement during cell division) and DNA topoisomerase I (regulates transcription). On the other hand, Scrambled siRNA sequence did not induce any negative effect on viability of MCF-7 cells (breast cancer) in the original study [25]. Thus, we can also assume cell type specific susceptibility towards investigated Scrambled siRNA.

The AE2G3 dendrimer allowed to prove the efficiency of multi-target approach involving RNAi-based gene downregulation and chemotherapeutic treatment to tackle cancer. Three different siRNAs against pro-survival genes of BCL-2 family acting by different mechanisms were successfully delivered by the AE2G3 dendrimer and revealed their potency through suppressing the viability of cancer cells. In low doses ( $~ 8.3 \mathrm{nM}$ for each siRNA as a part of $25 \mathrm{nM}$ cocktail), siRNA cocktail improved the anticancer effect of 5-fluorouracil, a drug acting through inhibition of thymidylate synthase and incorporation of its metabolites into RNA and DNA [43]. Since the combination effects were consistent with the individual potencies of dendriplexes and 5-FU, we assume additivity of dendriplexes and 5-FU action. It should be noted that assessment of combined effects using methods involving combination indices [44] was hindered by inability to determine accurate dose-effect response of dendriplexes, since siRNA cannot internalize and exhibit any biological response in absence of dendrimers, which, in our case, can also affect the viability.

The higher cytotoxic effect of dendriplexes bearing the cocktail of pro-apoptotic siRNAs formed at CR 10:1 compared with those formed at 5:1 requires further investigation. We can assume that an excess of positive charge is crucial in interactions with negatively charged plasmatic membrane in the conditions of inalienable presence of proteins in surrounding media (as FBS in vitro as serum proteins in vivo).

Several studies have reported that an excess of positive charges is important for genetic material transfection because it facilitates interaction with the cell membrane and consequently the internalization [45-47]. For this reason, we used 10-fold surplus of positive charges in transfection experiments. However, we can make an assumption that an excess of dendrimers' positive charges is crucial for the effective transfection, not only due to promoted cell entry, but is also related to the interactions with serum proteins. Positively charged dendrimers tend to associate with serum proteins, including serum albumins [48-50] and regulatory proteins [51,52]. On one hand, this can reduce dendrimers' cytotoxicity since their surface functional groups might be shielded by proteins. On the other hand, proteins are often considered as an obstacle for transfection, raising an issue of serum stability: interactions with proteins can cause disassembly of dendriplexes, and aggregation with proteins can lead to rapid blood elimination [53]. In case of diethylamine-terminated CPD, the presence of serum contributed to more effective transfection and lowered dendrimers' cytotoxicity [13]. High internalization rates of AE2-based dendriplexes in the presence of $10 \%$ FBS indicate possibility of using of AE2 dendrimers for delivery of siRNAs in the environment containing proteins and suggest serum stability of the dendriplexes in vitro.

\section{Conclusions}

In the present work, we synthesized new cationic phosphorus dendrimers (generations 3 and 4) bearing piperidine cations on the periphery and tested them as carriers of anti-apoptotic siRNAs 
(siBCL-xL, siBCL-2 and siMCL-1). We investigated their ability to form the complexes with siRNA and to deliver genetic material inside tumor cells, as well as the ability of siRNAs, delivered by means of these dendrimers to inhibit cancer cell growth within a multi-target approach involving combination with chemotherapeutic drug 5-FU.

Novel dendrimers of both generations demonstrated excellent ability to bind siRNAs, confirmed by circular dichroism, zeta-potential and gel electrophoresis, forming stable dendriplexes at 5 -fold excess of dendrimers positive charges over negative charges of siRNAs. These dendrimers provided 80-100\% siRNA uptake by HeLa cells in the serum containing medium, while the widespread transfection agent Lipofectamine showed only $\sim 40 \%$ uptake. Among two generations of dendrimers, the AE2G3 dendrimer demonstrated better efficiency when tested for cancer cell inhibition by the cocktail of pro-apoptotic siRNAs. We also demonstrated considerable increase of 5-FU cytotoxic effect by addition of AE2G3/siRNA cocktail dendriplexes in low doses.

The allocation of charge in terminal groups and their size, differing from diethylamine-terminated $\mathrm{CPD}$, endows piperidine-terminated dendrimers with the properties of being an outstanding carrier for siRNA delivery to cancer cells. Presumably, grafting of piperidine on the periphery of phosphorus dendrimers provides optimal interrelation between siRNA binding and intracellular release, taking into account the size of a dendrimer molecule of the $3^{\text {rd }}$ generation.

The newly synthesized AE2G3 phosphorus dendrimer can find an application in RNAi-based approaches to cancer treatment and could also be applied as an efficient vehicle for gene-based drugs in transfection studies. The application of multi-target RNAi-based approach with a chemotherapeutic combination using piperidine-terminated dendrimers paves the way to a new strategy in anti-cancer nanomedicine development.

Supplementary Materials: The supplementary materials are available online at www.mdpi.com/2504-5377/1/ $1 / 6 /$ s1.

Acknowledgments: This work has been supported by Grants B15RM-060, M15CO-041 from the Belarusian Republican Foundation for Fundamental Research; by Grant 16-33-60152_mol_a_dk from the Russian Foundation for Basic Research; by the Russian State funded budget project (VI.62.1.4, 0309-2016-0004); by the Scholarship of the President of the Russian Federation (Grant 882.2016.4); by a Marie Curie International Research Staff Exchange Scheme Fellowship within the 7th European Community Framework Programme, project No. PIRSES-GA-2012-316730 NANOGENE. Thanks are due to the National Center for Scientific Research (CNRS, France) for financial support.

Author Contributions: M.I., D.S., A.V., M.A.M.-F., S.M., J.-P.M. and M.B. designed the research; A.I.-K. performed the assessment of cancer cell growth inhibition and analyzed the data, V.D. performed cellular uptake experiments, S.L., K.M., E.A., M.I., O.K. performed complex formation studies; E.A. synthesized the dendrimers; O.K. synthesized the siRNAs; A.I.-K., E.A., M.I. and D.S. drafted the manuscript, the other authors revised it critically. All authors have given approval to the final version of the manuscript.

Conflicts of Interest: The authors declare no conflict of interest.

\section{References}

1. Agrawal, N.; Dasaradhi, P.V.N.; Mohmmed, A.; Malhotra, P.; Bhatnagar, R.K.; Mukherjee, S.K. RNA interference: Biology, mechanism, and applications. Microbiol. Mol. Biol. Rev. 2003, 67, 657-685. [CrossRef] [PubMed]

2. Resnier, P.; Montier, T.; Mathieu, V.; Benoit, J.P.; Passirani, C. A review of the current status of siRNA nanomedicines in the treatment of cancer. Biomaterials 2013, 34, 6429-6443. [CrossRef] [PubMed]

3. Wang, J.; Lu, Z.; Wientjes, M.G.; Au, J.L.S. Delivery of siRNA Therapeutics: Barriers and Carriers. AAPS J. 2010, 12, 492-503. [CrossRef] [PubMed]

4. Menjoge, A.R.; Kannan, R.M.; Tomalia, D.A. Dendrimer-based drug and imaging conjugates: Design considerations for nanomedical applications. Drug Discov. Today 2010, 15, 171-185. [CrossRef] [PubMed]

5. Biswas, S.; Torchilin, V.P. Dendrimers for siRNA delivery. Pharmaceuticals 2013, 6, 161-183. [CrossRef] [PubMed]

6. Wu, J.; Huang, W.; He, Z. Dendrimers as carriers for siRNA delivery and gene silencing: A review. Sci. World J. 2013, 2013. [CrossRef] [PubMed] 
7. Kannan, R.M.; Nance, E.; Kannan, S.; Tomalia, D.A. Emerging concepts in dendrimer-based nanomedicine: From design principles to clinical applications. J. Intern. Med. 2014, 276, 579-617. [CrossRef] [PubMed]

8. Caminade, A.M.; Majoral, J.P. Biological Properties of Phosphorus Dendrimers. In Dendrimer-Based Drug Delivery Systems: From Theory to Practice; John Wiley \& Sons: Hoboken, NJ, USA, 2012; pp. 139-155, ISBN 9780470460054.

9. Caminade, A.-M.; Majoral, J.-P. Positively charged phosphorus dendrimers. An overview of their properties. New J. Chem. 2013, 37, 3358-3373. [CrossRef]

10. Mignani, S.; Majoral, J.-P. Dendrimers as macromolecular tools to tackle from colon to brain tumor types: A concise overview. New J. Chem. 2013, 37, 3337-3357. [CrossRef]

11. Wasiak, T.; Marcinkowska, M.; Pieszynski, I.; Zablocka, M.; Caminade, A.-M.; Majoral, J.-P.; Klajnert-Maculewicz, B. Cationic phosphorus dendrimers and therapy for Alzheimer's disease. New J. Chem. 2015, 39, 4852-4859. [CrossRef]

12. Mignani, S.; Bryszewska, M.; Zablocka, M.; Klajnert-Maculewicz, B.; Cladera, J.; Shcharbin, D.; Majoral, J.P. Can dendrimer based nanoparticles fight neurodegenerative diseases? Current situation versus other established approaches. Prog. Polym. Sci. 2017, 64, 23-51. [CrossRef]

13. Loup, C.; Zanta, M.; Caminade, A. Preparation of Water-Soluble Cationic Phosphorus-Containing Dendrimers. Chem. Eur. J. 1999, 5, 3644-3650. [CrossRef]

14. Maszewska, M.; Leclaire, J.; Cieslak, M.; Nawrot, B.; Okruszek, A.; Caminade, A.-M.; Majoral, J.-P. Water-soluble polycationic dendrimers with a phosphoramidothioate backbone: Preliminary studies of cytotoxicity and oligonucleotide/plasmid delivery in human cell culture. Oligonucleotides 2003, 13, 193-205. [CrossRef] [PubMed]

15. Shcharbin, D.; Dzmitruk, V.; Shakhbazau, A.; Goncharova, N.; Seviaryn, I.; Kosmacheva, S.; Potapnev, M.; Pedziwiatr-Werbicka, E.; Bryszewska, M.; Talabaev, M.; et al. Fourth generation phosphorus-containing dendrimers: Prospective drug and gene delivery carrier. Pharmaceutics 2011, 3, 458-473. [CrossRef] [PubMed]

16. Briz, V.; Serramía, M.J.; Madrid, R.; Hameau, A.; Caminade, A.-M.; Majoral, J.P.; Muñoz-Fernández, M. A Validation of a generation 4 phosphorus-containing polycationic dendrimer for gene delivery against HIV-1. Curr. Med. Chem. 2012, 19, 5044-5051. [CrossRef] [PubMed]

17. Dzmitruk, V.; Szulc, A.; Shcharbin, D.; Janaszewska, A.; Shcharbina, N.; Lazniewska, J.; Novopashina, D.; Buyanova, M.; Ionov, M.; Klajnert-Maculewicz, B. Anticancer siRNA cocktails as a novel tool to treat cancer cells. Part (B). Efficiency of pharmacological action. Int. J. Pharm. 2015, 485, 288-294. [CrossRef] [PubMed]

18. Padié, C.; Maszewska, M.; Majchrzak, K.; Nawrot, B.; Caminade, A.M.; Majoral, J.P. Polycationic phosphorus dendrimers: Synthesis, characterization, study of cytotoxicity, complexation of DNA, and transfection experiments. New J. Chem. 2009, 33, 318-326. [CrossRef]

19. Ferenc, M.; Pedziwiatr-Werbicka, E.; Nowak, K.E.; Klajnert, B.; Majoral, J.P.; Bryszewska, M. Phosphorus dendrimers as carriers of siRNA-characterisation of dendriplexes. Molecules 2013, 18, 4451-4466. [CrossRef] [PubMed]

20. Ionov, M.; Lazniewska, J.; Dzmitruk, V.; Halets, I.; Loznikova, S.; Novopashina, D.; Apartsin, E.; Krasheninina, O.; Venyaminova, A.; Milowska, K.; et al. Anticancer siRNA cocktails as a novel tool to treat cancer cells. Part (A). Mechanisms of interaction. Int. J. Pharm. 2015, 485, 261-269. [CrossRef] [PubMed]

21. Lazniewska, J.; Milowska, K.; Zablocka, M.; Mignani, S.; Caminade, A.M.; Majoral, J.P.; Bryszewska, M.; Gabryelak, T. Mechanism of cationic phosphorus dendrimer toxicity against murine neural cell lines. Mol. Pharm. 2013, 10, 3484-3496. [CrossRef] [PubMed]

22. Izquierdo, M. Short interfering RNAs as a tool for cancer gene therapy. Cancer Gene Ther. 2005, 12, $217-227$. [CrossRef]

23. Lessene, G.; Czabotar, P.E.; Colman, P.M. BCL-2 family antagonists for cancer therapy. Nat. Rev. Drug Discov. 2008, 7, 989-1000. [CrossRef]

24. Brotin, E.; Meryet-Figuière, M.; Simonin, K.; Duval, R.E.; Villedieu, M.; Leroy-Dudal, J.; Saison-Behmoaras, E.; Gauduchon, P.; Denoyelle, C.; Poulain, L. Bcl-XL and MCL-1 constitute pertinent targets in ovarian carcinoma and their concomitant inhibition is sufficient to induce apoptosis. Int. J. Cancer 2010, 126, 885-895.

25. Vestin, A.; Khazanov, E.; Avni, D.; Sergeyev, V.; Barenholz, Y.; Sidi, Y.; Yakobson, E. siRNA-lipoplex-mediated Bcl-2 and Bcl-xL gene silencing induces apoptosis in MCF-7 human breast carcinoma cells. Open Chem. Biomed. Methods J. 2008, 1, 28-43. [CrossRef] 
26. Aliabadi, H.M.; Mahdipoor, P.; Uludağ, H. Polymeric delivery of siRNA for dual silencing of Mcl-1 and P-glycoprotein and apoptosis induction in drug-resistant breast cancer cells. Cancer Gene Ther. 2013, 20, 169-177. [CrossRef]

27. Takahashi, H.; Chen, M.C.; Pham, H.; Matsuo, Y.; Ishiguro, H.; Reber, H.A.; Takeyama, H.; Hines, O.J.; Eibl, G. Simultaneous knock-down of Bcl-xL and Mcl-1 induces apoptosis through Bax activation in pancreatic cancer cells. Biochim. Biophys. Acta Mol. Cell Res. 2013, 1833, 2980-2987. [CrossRef] [PubMed]

28. Karami, H.; Baradaran, B.; Esfehani, A.; Sakhinia, M.; Sakhinia, E. Down-regulation of Mcl-1 by small interference RNA induces apoptosis and sensitizes HL-60 leukemia cells to etoposide. Asian Pac. J. Cancer Prev. 2014, 15, 629-635. [CrossRef]

29. Chetoui, N.; Sylla, K.; Gagnon-Houde, J.-V.; Alcaide-Loridan, C.; Charron, D.; Al-Daccak, R.; Aoudjit, F. Down-regulation of mcl-1 by small interfering RNA sensitizes resistant melanoma cells to fas-mediated apoptosis. Mol. Cancer Res. 2008, 6, 42-52. [CrossRef]

30. Nakamura, K.; Lila, A.A.S.; Matsunaga, M.; Doi, Y.; Ishida, T.; Kiwada, H. A Double-modulation Strategy in Cancer Treatment With a Chemotherapeutic Agent and siRNA. Mol. Ther. 2011, 19, 2040-2047. [CrossRef]

31. Mosmann, T. Rapid colorimetric assay for cellular growth and survival: Application to proliferation and cytotoxicity assays. J. Immunol. Methods 1983, 65, 55-63. [CrossRef]

32. Launay, N.; Caminade, A.-M.; Majoral, J.P. Synthesis of bowl-shaped dendrimers from generation 1 to generation 8. J. Organomet. Chem. 1997, 529, 51-58. [CrossRef]

33. El Kazzouli, S.; Mignani, S.; Bousmina, M.; Majoral, J.-P. Dendrimer therapeutics: Covalent and ionic attachments. New J. Chem. 2012, 36, 227-240. [CrossRef]

34. Mignani, S.; El Kazzouli, S.; Bousmina, M.; Majoral, J.P. Dendrimer space concept for innovative nanomedicine: A futuristic vision for medicinal chemistry. Prog. Polym. Sci. 2013, 38, 993-1008. [CrossRef]

35. Tomalia, D.A. In quest of a systematic framework for unifying and defining nanoscience. J. Nanopart. Res. 2009, 11, 1251-1310. [CrossRef]

36. Tomalia, D.A. Dendritic effects: Dependency of dendritic nano-periodic property patterns on critical nanoscale design parameters (CNDPs). New J. Chem. 2012, 36, 264-281. [CrossRef]

37. Tomalia, D.A.; Khanna, S.N. A systematic framework and nanoperiodic concept for unifying nanoscience: Hard/soft nanoelements, superatoms, meta-Atoms, new emerging properties, periodic property patterns, and predictive mendeleev-like nanoperiodic tables. Chem. Rev. 2016, 116, 2705-2774. [CrossRef]

38. Govender, P.; Renfrew, A.K.; Clavel, C.M.; Dyson, P.J.; Therrien, B.; Smith, G.S. Antiproliferative activity of chelating $\mathrm{N}, \mathrm{O}$ - and $\mathrm{N}, \mathrm{N}$-ruthenium(II) arene functionalised poly(propyleneimine) dendrimer scaffolds. Dalton Trans. 2011, 40, 1158-1167. [CrossRef]

39. Michlewska, S.; Ionov, M.; Shcharbin, D.; Maroto-Díaz, M.; Ramirez, R.G.; de la Mata, F.J.; Bryszewska, M. Ruthenium metallodendrimers with anticancer potential in an acute promyelocytic leukemia cell line (HL60). Eur. Polym. J. 2016, 87, 39-47. [CrossRef]

40. Kim, S.-S.; Garg, H.; Joshi, A.; Manjunath, N. Strategies for targeted nonviral delivery of siRNAs in vivo. Trends Mol. Med. 2009, 15, 491-500. [CrossRef]

41. Kesharwani, P.; Iyer, A.K. Recent advances in dendrimer-based nanovectors for tumor-targeted drug and gene delivery. Drug Discov. Today 2015, 20, 536-547. [CrossRef]

42. Hannus, M.; Beitzinger, M.; Engelmann, J.C.; Weickert, M.T.; Spang, R.; Hannus, S.; Meister, G. SiPools: Highly complex but accurately defined siRNA pools eliminate off-target effects. Nucleic Acids Res. 2014, 42, 8049-8061. [CrossRef]

43. Longley, D.B.; Harkin, D.P.; Johnston, P.G. 5-Fluorouracil: Mechanisms of action and clinical strategies. Nat. Rev. Cancer 2003, 3, 330-338. [CrossRef]

44. Foucquier, J.; Guedj, M. Analysis of drug combinations: Current methodological landscape. Pharmacol. Res. Perspect. 2015, 3, e00149. [CrossRef]

45. Ruponen, M.; Ylä-Herttuala, S.; Urtti, A. Interactions of polymeric and liposomal gene delivery systems with extracellular glycosaminoglycans: Physicochemical and transfection studies. Biochim. Biophys. Acta (BBA) Biomembr. 1999, 1415, 331-341. [CrossRef]

46. Navarro, G.; de ILarduya, C.T. Activated and non-activated PAMAM dendrimers for gene delivery in vitro and in vivo. Nanomed. Nanotechnol. Biol. Med. 2009, 5, 287-297. [CrossRef]

47. Dennig, J. Gene transfer in eukaryotic cells using activated dendrimers. In Dendrimers $V$; Springer: Berlin/Heidelberg, Germany, 2003; pp. 227-236. 
48. Klajnert, B.; Stanislawska, L.; Bryszewska, M.; Bartlomiej, P. Interactions between PAMAM dendrimers and bovine serum albumin. Biochim. Biophys. Acta 2003, 1648, 115-126. [CrossRef]

49. Froehlich, E.; Mandeville, J.S.; Jennings, C.J.; Sedaghat-Herati, R.; Tajmir-Riahi, H.A. Dendrimers bind human serum albumin. J. Phys. Chem. B 2009, 113, 6986-6993. [CrossRef]

50. Mandeville, J.S.; Tajmir-Riahi, H.A. Complexes of dendrimers with bovine serum albumin. Biomacromolecules 2010, 11, 465-472. [CrossRef]

51. Szwed, A.; Milowska, K.; Ionov, M.; Shcharbin, D.; Moreno, S.; Gomez-Ramirez, R.; de la Mata, F.J.; Majoral, J.P.; Bryszewska, M.; Gabryelak, T. Interaction between dendrimers and regulatory proteins. Comparison of effects of carbosilane and carbosilane-viologen-phosphorus dendrimers. RSC Adv. 2016, 6, 97546-97554. [CrossRef]

52. Ionov, M.; Ihnatsyeu-Kachan, A.; Michlewska, S.; Shcharbina, N.; Shcharbin, D.; Majoral, J.-P.; Bryszewska, M. Effect of dendrimers on selected enzymes-Evaluation of nano carriers. Int. J. Pharm. 2016, 499, $247-254$. [CrossRef]

53. Aied, A.; Greiser, U.; Pandit, A.; Wang, W. Polymer gene delivery: Overcoming the obstacles. Drug Discov. Today 2013, 18, 1090-1098. [CrossRef]

(C) 2017 by the authors. Licensee MDPI, Basel, Switzerland. This article is an open access article distributed under the terms and conditions of the Creative Commons Attribution (CC BY) license (http:/ / creativecommons.org/licenses/by/4.0/). 